\title{
Factors Affecting on Users' Intentions toward 4G Mobile Services in Bangladesh
}

\author{
Mohammad Abid Hasan \\ Lecturer, Business Administration, Varendra University, Rajshahi, BANGLADESH \\ *E-mail for correspondence: abidhasan49@gmail.com
}

https://doi.org/10.18034/abr.v9i1.220

\begin{abstract}
This study discusses the amalgamation of Technology Acceptance Model with the underlying 8 factors to investigate the intensity of users' intentions towards 4G adoptions in Bangladesh. So, it has tried to list all the latest released facilities and the adoption tendency. A sample size of 119 respondents with random sampling as well as in-depth interviewing methods have used and collected primary data from different institutions across Bangladesh with a self-administered field survey questionnaire as well as having secondary sources from different webs, books, journals, annual reports, and unpublished research works. The SPSS and the 5-Point-Likert scale have used to validate the results. Also the tests include correlation, multiple regression technique, ANOVA, and co-efficient of variance have used. The study indicates that $36 \%$ respondents are positively prone to $4 \mathrm{G}\left(r^{2}=.362, f=5.531\right.$, $p=.000$ ). Besides, among the 8 factors, the image has the greatest influence on it $(\beta=.249, t=2.558, p=.012)$ followed by the variety of services $(\beta=.189, t=1.608, p=.111)$, the perceived enjoyment $(\beta=.148, t=1.803$, $p=0.109)$, the perceived ease of use $(\beta=0.108, t=0.916, p=0.368)$, the personal Innovativeness $(\beta=.098$, $t=.934, p=.352)$, and the network effects $(\beta=.002, t=.025, p=.980)$. Conversely, the price $(\beta=-.027, t=-.406$, $p=.685)$ and the perceived usefulness $(\beta=-.069, t=-.629, p=.303)$ have a rare impact on it. However, with the outcomes, the telecommunication services providers will be able to accelerate the wining strategies at different levels in Bangladesh. As there are few studies published in this regard, future research is necessary to investigate the financial and industrial implications associated with it.
\end{abstract}

Key words: Perceived Usefulness, Variety of Services, Perceived Enjoyment, Image, Personal Innovativeness, Network Effects, Price

\section{INTRODUCTION}

Due to widespread demand as a means of communication, the mobile services market is being as the most rational part in the telecommunications sector. The fourth-generation mobile communication service, $4 \mathrm{G}$, is a combination of $3 G$ as well as having the high-quality image and video transmission with a high definition television technology (Velmurugan \& Velmurugan, 2017). It has opened up doors for high-speed transfer of both voice and data (Parikh \& Basu, 2011). One of the reasons for shifting $3 \mathrm{G}$ to $4 \mathrm{G}$ among the users is that $3 \mathrm{G}$ does not concentrate on developing its technical standards ( $\mathrm{Xu}$ et al., 2017). 4G services are now providing high-speed communication facilities around the globe via more updated applications in mobile phoNE which were not possible by previous technology (Campilho \& Kamel, 2004). Now, it has brought easy intranet/extranet access, customized infotainment, multimedia messaging service (MMS), mobile internet access, location-based services, rich voice, and so forth. Mobile intranet/extranet access is a busiNEs service that allows the safe access to local area networks (LAN) and virtual private networks (VPN) (Hwang et al., 2007). Location-based services allow users to identify their locations, terminals of transportations, the position of vehicles, and the advanced voice capabilities, for example, VoIP, Web-initiated phone calls, etc. (UMTS Report, 2000a). The adoption tendencies of mobile services such as video and multimedia messaging have increased together with the progress of the $4 \mathrm{G}$. This modern technology reached 100 million subscriptions, with a rate of 3 million subscribers per month (UMTS Forum, 2001b \& 2006c). It also reported that "by 2010, subscribers will spend about $\$ 30$ per month for $4 \mathrm{G}$ services and total $4 \mathrm{G}$ services provider retained revenues will exceed \$ 300 million." 


\section{Inauguration and present $4 \mathrm{G}$ status in Bangladesh}

In February 2018, 4G arrived in Bangladesh through Teletalk, Robi, Grammenphone, and Banglalink (The Daily Star, 2018). As of 2018, Android has over $80 \%$ global market share having nice polyphonic ringtoNE, FM radio, $3.5 \mathrm{~mm}$ jack, fun and games, Bluetooth and some of them also had a standard quality back camera (The Economic Times, \& ETTelecom, 2018). $4 \mathrm{G}$ has been the latest as well as the fastest growing mobile services and provides the high-speed internet facilities in Bangladesh (bdnews24.com, 2018). It can download at a speed of $100 \mathrm{Mbps}$, and meet nearly all the user's requirements (The Daily Star, 2018). Users are getting entertainment through mobile TV at any 4G coverage areas, and also enjoying many Bangladeshi TV Channels including BTV, Channel I, Independent, and IP TVs , as for example, Cartoon TV, Travel TV, Bollywood TV, etc (Hassan et al., 2015). Nowadays, subscribers are being able to make video calling and communicate people who are distant, share a story, celebrate a birthday, hold a meeting, work with colleagues, etc. (He \& Zhao, 2008). In Bangladesh, the major services provided by it are mobile TV, video calling, video on demand, enhance voice telephony, other upload-download services, video conferencing, navigation on transportation, city surveillance, etc., (Dhaka Tribune, 2018).

\section{REVIEW OF LITERATURE}

Users are enjoying the high-speed internet facilities and a variety of services from internet service providers (ISP) with reasonable price in Bangladesh (Dhaka Tribune, 2018). Some researchers also developed different models to understand the consumer behaviours and attitudes towards the adoption tendency of innovated technologies (Sirdeshmukh et al., Lin et al., Ha., Li, 2018; Venkatesh \& Davis, 2000; \& Rogers, 1995). Besides, this study has not found sufficient numbers of related studies towards the $4 \mathrm{G}$ adoption in Bangladesh, is an attempt to mitigate the research gap in this regard. Thus, the paper aims at identifying the factors influencing on it. Recently this service is tremendously developing itself technically and conveniently. This study has reviewed many articles related to current $4 \mathrm{G}$ adoption tendency, customer behavior, customer segmentation, acceptance, and features that affect use in various countries. In 2009, TeliaSonera introduced it in Stockholm and Oslo commercially; a year later in Finland, and in 2014, it offered 4G in 10 states (Jansson, Karin. n.d.). By drawing the Technology Acceptance Model (TAM), this study has examined the factors influencing the intentions towards $4 \mathrm{G}$ in Bangladesh.

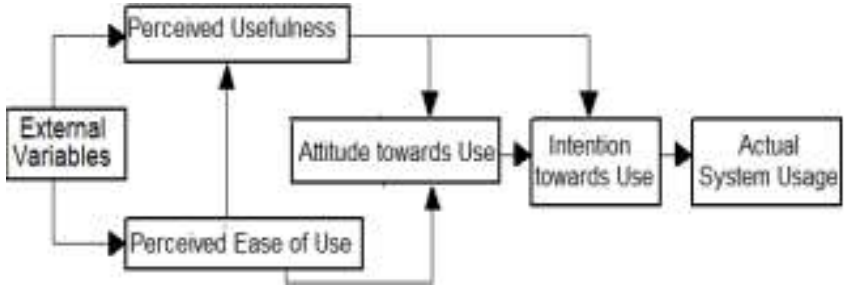

Figure 1: The Technology Acceptance Model (TAM)

\section{Research Methodology}

\section{Sampling size and plan}

Lack of time and resources, a sample size of 119 respondents have used. The study has spent some days for planning a sample size and collected data from different institutions like Rajshahi University, Rajshahi University of Engineering \& Technology, Rajshahi College, Varendra University, and more government and private educational institutions from 7 divisions of Bangladesh like Dhaka, Khulna, Barisal, Chittagong, Sylhet, Mymensingh, Rangpur, etc. It has also collected data from Boshundhara City, Jamuna Future Park, Banglalink customer care points, Grameen Phone customer care points, Robi customer care points, Airtel customer care houses, different banks like Bangladesh Bank, MBBL, MTB, NCCB, Dutch Bangla Bank First Track, and so forth. It took time because respondents were from all parts of Bangladesh and not always in the mood to talk, and sometimes different types of complications arose so that the study had to wait to make a favorable scope. But at last the sampling plan was done appropriately and the study got the desired outcomes.

\section{Sampling method and source of data}

This study has used random sampling as well as in-depth interviewing methods, and focused on primary data collected from various educational, government and private institutions from Bangladesh with a self-administrated questionnaire. The secondary sources include different webs, online published articles, blogs, books, journals, annual reports, and unpublished research works.

\section{Types of tests and statistical software applied}

The study has used SPSS statistical software and Likert scale to analyze the relationship among different properties in the proposed model and to identify the respondents' intentions towards $4 \mathrm{G}$ acceptance. The test includes correlation; multiple regression technique, ANOVA, and co-efficient of variance.

\section{THEORETICAL FRAMEWORK}

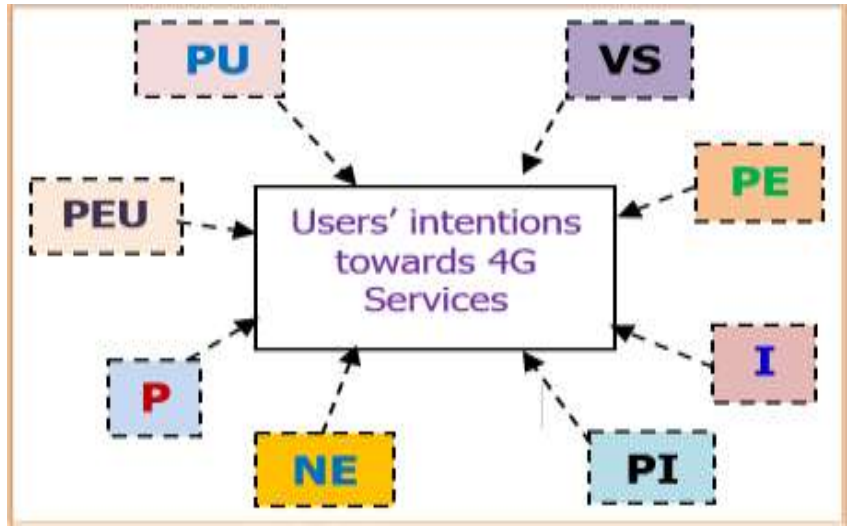

Figure 2: Proposed research model 


\section{Critical factors affecting acceptance of $4 \mathrm{G}$ and hypothesis}

After going through different kinds of innovationadoption literature, the study found that there are several factors behind the $4 \mathrm{G}$ acceptance in Bangladesh which are identified as more influential and described as following categories.

Perceived Usefulness (PU): According to the TAM model by Davis et al. (1989), perceived usefulness is a critical factor with the name of "relative advantage" in adoption of a technology. Hence, for the sake of $4 \mathrm{G}$ acceptability in Bangladesh, it is considered influential.

$\mathrm{H}_{1}$ : PU influences positively on $4 \mathrm{G}$ acceptance.

Variety of Services (VS): It refers to the availability of functions, such as MS Office compatibility, download facilities, organizer functions, games, other mobile apps, etc. (Hassan et al., 2015). The more services are, the more powerful the technology is. $4 \mathrm{G}$ provides a wide variety of audios, videos and data services, faster and better games, location services, televisions, etc. (Dhaka Tribune, 2018).

$\mathrm{H}_{2}$ : VS influences on $4 \mathrm{G}$ acceptance.

Perceived Enjoyment (PE): Fundamentally PE means having fun, gaming on mobiles, watching movies on entertainment appliances, traveling with peers, etc. (Velmurugan \& Velmurugan, 2017). Hence, concerning the $4 \mathrm{G}$ acceptance in Bangladesh, this element is considered influential.

$\mathrm{H}_{3}$ : PE influences on $4 \mathrm{G}$ acceptance.

Image (I): The image refers to a symbolic status in a telecommunication industry which ensures the perceived relative advantages among the users. It has a social influence which affects the acceptance of innovations (Hassan et al., 2015).

$\mathrm{H}_{4}$ : Image influences on $4 \mathrm{G}$ acceptance.

Personal Innovativeness (PI): According to Rogers (1995), "personal characteristics highly affect decisions to adopt or reject innovation." Other researchers have claimed that "individuals, who have high Innovativeness, are more likely to develop positive perceptions towards the innovation" (KoschateFischer et al., 2018).

$\mathrm{H}_{5}$ : PI influences on $4 \mathrm{G}$ acceptance.

Network Effects (NE): NE provides a technical support that can ensure the uninterruptable speed of internet access which plays a crucial role in the adoption of communication technology (Pagani, 2004). Hence, $\mathrm{NE}$ tends to impact on $4 \mathrm{G}$ adoption.

$\mathrm{H}_{6}$ : NE influences on $4 \mathrm{G}$ acceptance.
Price $(\mathrm{P})$ : Sellers can manipulate customer's perceived price by providing reference price, such as the price from the other vendors, etc. (Koschate-Fischer et al., 2018; Martins \& Monroe, 1994). The studies also suggested that the external reference price derives from the observation of the vendor's promotional or advertised price and the internal reference price resides within the customer's memory which impacts on adoption of innovation.

$\mathrm{H}_{7}$ : Price influences on $4 \mathrm{G}$ acceptance.

Perceived Ease of Use (PEU): It indicates that how conveniently and effortlessly users are getting services. So, it also refers easily to use and less difficult to adopt the new technology by users (Hassan et al., 2015).

H8: $\quad$ PEU influences on $4 \mathrm{G}$.

\section{Results AND Discussions}

Table 1: Socio-demographic characteristics of the respondents

\begin{tabular}{|c|c|c|}
\hline Gender & Frequency & Percent \\
\hline Male & 84 & 70.6 \\
\hline Female & 35 & 29.4 \\
\hline Total & 119 & 100 \\
\hline Age range & Number & Percent \\
\hline $15-25$ & 76 & 63.9 \\
\hline $26-35$ & 35 & 29.4 \\
\hline $36-45$ & 5 & 4.2 \\
\hline $46-55$ & 3 & 2.5 \\
\hline Total & 119 & 100 \\
\hline Occupations & Number & Percent \\
\hline Teaching & 13 & 10.9 \\
\hline Doctor & 1 & 0.8 \\
\hline Government Job & 2 & 1.7 \\
\hline Private Company & 3 & 2.5 \\
\hline Multinational Corporation & 2 & 1.7 \\
\hline NRB (Non-Resident of Bangladesh) & 1 & 0.8 \\
\hline Business & 4 & 3.4 \\
\hline Bank Job & 9 & 7.6 \\
\hline NGO & 1 & 0.8 \\
\hline Self Employed & 1 & 0.8 \\
\hline Housewife & 1 & 0.8 \\
\hline Student & 78 & 65.5 \\
\hline Unemployed & 2 & 1.7 \\
\hline Others & 1 & 0.8 \\
\hline Total & 119 & 100 \\
\hline Marital status & Number & Percent \\
\hline Marred & 33 & 27.7 \\
\hline Single & 84 & 70.6 \\
\hline Separated & 2 & 1.7 \\
\hline Total & 119 & 100 \\
\hline
\end{tabular}

Source: Author's field survey, 2018

The study found the results (Table 1) from the sociodemographic characteristics of the respondents that 
among the 100 respondents, the numbers of males and females were respectively $84(70.6 \%)$, and $35(29.4 \%)$; the group of age range 15-25 had more tendency to adopt the $4 \mathrm{G}$; around $84(70.6 \%)$ were single, $33(27.7 \%)$ were marred; the most of them were students and teachers respectively $78(65.5 \%)$, and $13(10.9 \%)$.

Table 2: Descriptive statistics of the respondents

\begin{tabular}{|c|c|c|c|c|c|}
\hline \multicolumn{6}{|c|}{ Perceived Usefulness (PU) } \\
\hline & $\begin{array}{c}\text { Respon } \\
\text { dent }\end{array}$ & \begin{tabular}{|l|} 
Mini \\
mum
\end{tabular} & Maxi & Mean & \begin{tabular}{c|} 
Std. \\
Deviation
\end{tabular} \\
\hline $\begin{array}{l}4 \mathrm{G} \text { increases the work } \\
\text { efficiency. }\end{array}$ & $\begin{array}{c}11 \\
9\end{array}$ & 1 & 5 & 4.07 & .778 \\
\hline $\begin{array}{l}\text { It increases the quality of } \\
\text { communication. }\end{array}$ & $\begin{array}{c}11 \\
9\end{array}$ & 1 & 5 & 3.77 & .797 \\
\hline \multicolumn{4}{|c|}{ Average mean } & 3.92 & \\
\hline \multicolumn{6}{|l|}{ Variety of Services (VS) } \\
\hline $\begin{array}{l}\text { It provides a wide variety } \\
\text { of services. }\end{array}$ & $\begin{array}{c}11 \\
9\end{array}$ & 1 & 5 & 3.73 & .841 \\
\hline \multicolumn{6}{|l|}{ Perceived Enjoyment (PE) } \\
\hline $\begin{array}{l}\text { It allows doing things } \\
\text { faster. }\end{array}$ & $\begin{array}{c}11 \\
9\end{array}$ & 1 & 5 & 3.92 & .885 \\
\hline $\begin{array}{l}\text { What kinds of basic } \\
\text { problems are you facing } \\
\text { for getting } 4 \mathrm{G} \text { services } \\
\text { from your mobile } \\
\text { operator? }\end{array}$ & $\begin{array}{c}11 \\
9\end{array}$ & 1 & 6 & 3.72 & 1.677 \\
\hline \multicolumn{4}{|c|}{ Average mean } & 3.82 & \\
\hline \multicolumn{6}{|l|}{ Image (I) } \\
\hline $\begin{array}{l}\text { Using } 4 \mathrm{G} \text { is a symbol of } \\
\text { prestige. }\end{array}$ & 119 & 1 & 5 & 3.48 & .901 \\
\hline \multicolumn{6}{|l|}{ Personal Innovativeness (PI) } \\
\hline $\begin{array}{l}\text { I like to purchase new } \\
\text { information/communicati } \\
\text { on technologies. }\end{array}$ & 119 & 2 & 5 & 3.96 & .706 \\
\hline \multicolumn{6}{|l|}{ Network Effects (NE) } \\
\hline $\begin{array}{l}\text { I think my mobile service } \\
\text { providers are interested to } \\
\text { provide } 4 \mathrm{G} \text {. }\end{array}$ & $\begin{array}{c}11 \\
9\end{array}$ & 1 & 5 & 3.90 & .906 \\
\hline \multicolumn{6}{|l|}{ Price $(\mathrm{P})$} \\
\hline $\begin{array}{l}\text { Using cost of } 4 \mathrm{G} \text { is } \\
\text { reasonable in Bangladesh. }\end{array}$ & 119 & 1 & 5 & 2.81 & 1.181 \\
\hline \multicolumn{6}{|l|}{ Perceived Ease of Use } \\
\hline $\begin{array}{l}\text { It is very easy to use } 4 \mathrm{G} \text { in } \\
\text { mobile. }\end{array}$ & 119 & 1 & 5 & 3.81 & .773 \\
\hline $\begin{array}{l}\text { It is compatible and user } \\
\text { friendly. }\end{array}$ & 119 & 1 & 5 & 3.81 & .762 \\
\hline \multicolumn{4}{|c|}{ Average mean } & 3.81 & \\
\hline \multicolumn{6}{|c|}{ Overall Customers' Intension } \\
\hline $\begin{array}{l}\text { Users of Bangladesh have } \\
\text { the favorable intention to } \\
\text { use } 4 \mathrm{G} \text {. }\end{array}$ & 119 & 1 & 5 & 3.65 & .898 \\
\hline
\end{tabular}

Source: Author's field survey, 2018

From the descriptive analysis (Table 2, 3, 4, 5, \& 6), the study found that $36 \%$ respondents are positively prone to $4 \mathrm{G}$ $\left(\mathrm{r}^{2}=.362, \mathrm{f}=5.531, \mathrm{p}=.000\right)$. Besides, among the 8 factors the image has the greatest influence on it $(\beta=.249, t=2.558$, $\mathrm{p}=.012)$ followed by the variety of services $(\beta=.189, \mathrm{t}=1.608$, $p=.111)$, the perceived enjoyment $(\beta=.148, t=1.803, p=0.109)$, the perceived ease of use $(\beta=0.108, t=0.916, p=0.368)$, the personal innovativeness $(\beta=.098, t=.934, p=.352)$, and the network effects $(\beta=.002, t=.025, p=.980)$. Conversely, the price $(\beta=-.027, t=-.406, p=.685)$ and the perceived usefulness $(\beta=-$ $.069, \mathrm{t}=-.629, \mathrm{p}=.303$ ) have a rare impact on it.

Table 3: Correlations

\begin{tabular}{|c|c|c|c|c|c|c|c|c|c|c|c|}
\hline & PU1 & PU2 & VS & PE1 & PE2 & I & PI & $\mathrm{NE}$ & $\mathrm{P}$ & PEU1 PEU2 & $\mathrm{OCI}$ \\
\hline PU1 & 1 & $.626^{* *}$ & $.689 * *$ & $.561^{* *}$ & .060 & $.280^{* *}$ & .036 & $.431^{* *}$ & .005 & $.458^{* *} .479^{* *}$ & $.374^{* *}$ \\
\hline PU2 & $.626^{* *}$ & 1 & $.516^{* *}$ & $.469^{* *}$ & .060 & $.436^{* *}$ & -.032 & $250^{* *}$ & .052 & $.355^{* *} .430^{* *}$ & $.231^{*}$ \\
\hline VS & $.689^{* *}$. & $.516^{* *}$ & 1 & $.428^{* *}$ & .061 & $.339^{* *}$ & .066 & $.309^{* *}$ & .058 & $.415^{* *} .4$ & \\
\hline PE1 & $.561^{* *}$. & $.469^{* *}$ & $.428^{* *}$ & 1 & .054 & $.376^{* *}$ & .063 & $.477^{* *}$ & .010 & $.375^{* *} .3$ & .436 \\
\hline PE2 & .060 & .060 & .061 & .054 & 1 & $.235^{*}$ & -.024 & .026 & -.100 & -.048 & $.182^{*}$ \\
\hline I & $.280^{* *}$ & $.436^{* *}$ & $.339 * *$ & $.376^{* *}$ & $.235^{*}$ & & .165 & $.299 * *$ & $.199^{*}$ & $.353^{* *} .383^{* *}$ & $.431 * *$ \\
\hline PI & .036 & -.032 & .066 & .063 & -.024 & .165 & 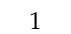 & .126 & $.285 * *$ & * $.171 \quad .205^{*}$ & .177 \\
\hline $\mathrm{NE}$ & $.431^{* *}$. & $.250^{* *}$ & $.309^{* *}$ & $.477^{* *}$ & .026 & $.299^{* *}$ & .126 & 1 & .140 & $.383^{* *} .426^{* *}$ & $.310^{* *}$ \\
\hline $\mathrm{P}$ & .005 & .052 & .058 & .010 & -.1 & $.199 *$ & $.285^{* *}$ & .140 & 1 & $.256^{* *} .288^{* *}$ & .079 \\
\hline EU1 & $.458^{* *}$ & $.355^{* *}$ & $.415^{* *}$ & $.375^{* *}$ & -.048 & $.353^{* *}$ & .171 & $.383^{* *}$. & $256^{* *}$ & * $\quad \begin{array}{ll}1 & .540^{* *}\end{array}$ & $.365^{* *}$ \\
\hline PEU2 & $.479^{* *}$ & $.430^{* *}$ & $.421^{* *}$ & $.368^{* *}$ & .064 & $.383^{* *}$ & $.205^{*}$ & $.426^{* *}$. & $.288^{* *}$ & $* .540^{* *} \quad 1$ & $.358^{* *}$ \\
\hline OCI & $.374^{* *}$ & $.231^{*}$ & $.401^{* *}$ & $.436^{* *}$ & $.182^{*}$ & $.431^{* *}$ & .177 & $.310^{* *}$ & .079 & $.365^{* *} .358^{*}$ & 1 \\
\hline
\end{tabular}

\section{Regression analysis}

This study used the multiple regression analyses technique to analyze the intensity of the 8 independent variables and a single dependent variable.

Table 4: Model summary

\begin{tabular}{|c|c|c|c|c|}
\hline Model & $\mathrm{R}$ & $\begin{array}{c}\mathrm{R} \\
\text { Square }\end{array}$ & $\begin{array}{c}\text { Adjusted } \\
\text { R Square }\end{array}$ & $\begin{array}{c}\text { Std. Error of } \\
\text { the Estimate }\end{array}$ \\
\hline 1 & $.602^{*}$ & .362 & .297 & .753 \\
\hline
\end{tabular}

*Predictors: (Constant), all the underlying eight factors and their associated attributes.

Table 5: ANOVA

\begin{tabular}{|c|c|c|c|c|c|}
\hline Model & Sum of Squares & df & Mean Square & F & Sig. \\
\hline Regression & 34.500 & 11 & 3.136 & 5.531 & .000 \\
\hline Residual & 60.676 & 107 & .567 & & \\
\hline Total & 95.176 & 118 & & & \\
\hline
\end{tabular}

a. Dependent Variable: Users of Bangladesh have the positive intention to use the $4 \mathrm{G}$.

b. Predictors: (Constant), all the underlying eight factors and their associated attributes.

Table 6: Coefficients

\begin{tabular}{|c|c|c|c|c|c|}
\hline & $\begin{array}{c}\text { Unstandardized } \\
\text { Coefficients }\end{array}$ & Coefficients & & & \\
\cline { 2 - 4 } & $\mathrm{B}$ & Std. Error & Beta & $\mathrm{t}$ & Sig. \\
\hline (Constant) & .265 & .591 & & .449 & .654 \\
\hline $\begin{array}{c}\text { Perceived } \\
\text { Usefulness }\end{array}$ & -.069 & .138 & -.062 & -.629 & .303 \\
\hline $\begin{array}{c}\text { Variety of } \\
\text { Services }\end{array}$ & .189 & .118 & .177 & 1.608 & .111 \\
\hline $\begin{array}{c}\text { Perceived } \\
\text { Enjoyment }\end{array}$ & .148 & .074 & .171 & 1.803 & .109 \\
\hline $\begin{array}{c}\text { Image } \\
\text { Imanonal }\end{array}$ & .249 & .097 & .250 & 2.558 & .012 \\
\hline $\begin{array}{c}\text { Personal } \\
\text { Innovativeness }\end{array}$ & .098 & .105 & .077 & .934 & .352 \\
\hline Network Effects & .002 & .094 & .002 & .025 & .980 \\
\hline
\end{tabular}




\begin{tabular}{|c|c|c|c|c|c|}
\hline Price & -.027 & .066 & -.035 & -.406 & .685 \\
\hline $\begin{array}{c}\text { Perceived } \\
\text { Ease of Use }\end{array}$ & .108 & .119 & .093 & .916 & .368 \\
\hline
\end{tabular}

a. Dependent variable: Overall customers' intentions

\section{Conclusion AND Recommendation}

\section{Conclusion}

This article has revealed the intensity of influence of the 8 factors that centerline the intention of using $4 \mathrm{G}$ in Bangladesh. It has exposed that the users' intentions towards $4 \mathrm{G}$ depend on the image, a variety of services, the perceived enjoyment, an ease of use, the personal innovativeness, and the network effects. On the other hand, the price of services and the usefulness have a rare positive impact on it but the adoption tendency of it has a great deal of potentiality. The outcomes of this research are very informative for Bangladeshi mobile service providers.

\section{Recommendation}

The major theoretical imposition in this study was to confirm the role of underlying 8 variables and their impacts on the adoption of 4G. Currently, the internet is providing a variety of enjoyment, for example, playing online games, downloading music and videos, chatting, and sending online messages (Tone et al., 2014). However, all these opportunities did not get the hope of light due to the slow speed of $3 \mathrm{G}(\mathrm{Xu}$ et al., 2017). But $4 \mathrm{G}$ has overcome all these complexities and now offers faster download speeds, streaming capabilities to internet users more conveniently. So, considering the 8 factors in $4 \mathrm{G}$ comparing to in $3 \mathrm{G}$, users who perceive $4 \mathrm{G}$ as a good means of entertainment will eventually adopt it. The findings support the underlying hypotheses that shape all factors will have a significant positive influence except the price and the usefulness on the attitude and behavioral intention toward using it. The broadband users are more likely to use the internet for amusement in comparison to narrowband users (Tone et al., 2014) which also support this study's findings. Moreover, the current findings have a significance on the understanding of the factors affecting users' intentions towards its acceptance which will be the useful suggestions for telecommunication services providers to make appropriate state-of-the-art strategies to attract the users and also recommends that the services providers must be careful about providing more variety of dynamic services in a convenient way. The study has some financial and time limitations, so future research is crucial to estimate and reinvestigate the possibility.

\section{REFERENCES}

bdnews24.com (2018, Oct 14) Bangladesh switches on the 4G wireless network as regulators license four operators. Retrieved from https://bdnews24.com/technology/2018/02/19/bangladeshswit ches-on-4g-wireless-network-as-regulators-licensefour-operators

Campilho, A., \& Kamel, M. (2004). Image analysis and recognition. ICIAR 2004: Proceedings, Springer. Retrieved from http:/ /books.google.com/books?id=26DOR_zVZL0C\&hl=tr
Davis, F. D. (1989). Perceived usefulness, perceived ease of use, and user acceptance of information technology. MIS Quarterly, 13 (3), 319-340.

Dhaka Tribune (2018, March 25). 4G boosts broadband internet speed. Retrieved from https:/ / www.dhakatribune.com/feature/tech/2018/03/1 8/4gboosts-broadband-internet-speed

ETTelecom (2018, August 30). Android phone to have 85\% global market share in 2018. Retrieved fromhttps:/ / telecom.economictimes.indiatimes.com/news /android-phoNE-to-have-85-globalmarket-share-in-2018idc/ 65609867

Ha, Youngwook. (2018). Expectations gap, anticipated regret, and behavior intention in the context of rapid technology evolvement. Industrial Management \& Data Systems, 118 (3), 606-617.

Hassan, Mohammad Masudul., Rahman, Airin., Rabbani, Md. Gulam., \& Resmi, Samira Islam. (2015). Factor affecting 3G mobile technology adoption in the context of Bangladesh: An empirical study. Applied Economics and Business Review, 17-27.

Hwang, Jun-Seok., Consulta, Roy R., \& Yoon, Hyunyoung. (2007). 4G mobile networks-technology beyond 2.5G and 3G. PTC'07 Proceedings. Retrieved from https://s3.amazonaws.com/academia.edu.documents/316521 83/T24_RoyConsulta.pdf?AWSAccessKeyId=AKIAIWOWYY GZ2Y53UL3A\&Expires $=1539493952 \&$ Signature $=p$ YdmorGG $\%$ 2BlUHxcGF9gvoPL9VpVc\%3D\&responsecontent228dispositio $\mathrm{n}=$ inline $\% 3 \mathrm{~B} \% 20$ filename\%3DT24_Roy_Consul ta.pdf

Jansson, Karin. (n.d.). First in the world with 4G. Telia Company. Retrieved from https:/ / www.teliacompany.com/en/aboutthecompany/history/first-in-the-world-with-4g/

Koschate-Fischer, N., Hoyer, W.D., Stokburger-Sauer, N.E. (2018). Do life events always lead to change in purchase? The mediating role of change in consumer innovativeness, the variety seeking tendency, and price consciousness. Journal of the Academy of Marketing Science, 46 (3), 516-536.

Li, Chia-Ying. (2018). Consumer behavior in switching between membership cards and mobile applications: The case of Starbucks. Computers in Human Behavior, 84, 171-184.

Lin, Xiaolin., Featherman, Mauricio., Brooks, Stoney L., \& Hajli, Nick. (2018). Exploring gender differences in online consumer purchase decision making: An online product presentation perspective. Information Systems Frontiers, 1-15.

Martins, M. \& Monroe, K.B. (1994). Perceived price fairness: a new look at an old construct. Advances in Consumer Research, $21,75-78$.

MobileDokan.com. Low price of $4 G$ smartphone in Bangladesh (n. d.). Retrieved from https://www.mobiledokan.com/cheap4g-smartphoneprice-in-bangladesh/

Pagani, M. (2004). The determinants of adoption of fourth generation mobile multimedia services. Journal of interactive marketing, 18 (3), 46-59.

Parikh, J. \& Basu, A. (2011). LTE advanced: The 4G mobile broadband technology. International Journal of Computer Applications, 13 (5), 1725.

Rogers, E. M. (1995). Diffusion of Innovations, 4th ed., New York: The Free Press. 
Sirdeshmukh, Deepak., B. Ahmad, Norita., Khan, M. Sajid., \& J. Ashill, Nicholas. (2018). Drivers of user loyalty intention and commitment to a search engine: An exploratory study. Journal of Retailing and Consumer Services, 44 , 71-81.

The Daily Star (2018, February 14) Bangladesh enters into the 4G era on Feb 19. Thedailystar.net. Retrieved from https:/ / www.thedailystar.net/frontpage/bangladeshenters4g-internet-service-era-on-february-19-2018-1534357

The Economic Times (2018, April 19). Want to ditch the smartphone? Try feature phone like Samsung Guru, Nokia 105. Retrieved from https:/ /economictimes.indiatimes.com/magazine/panach e/want-to-ditch-the-smartphone-try-feature-phonelikesamsung-guru-nokia-105/articleshow/63812993.cms

Tone, Hui-Jie., Zhao, Hao-Rui., \& Yan, Wan-Seng. (2014, January). The attraction of online games: An important factor for internet addiction. Computers in Human Behavior, 30, 321-327.

UMTS Forum (2006c). 4G/UMTS evolution: towards a new generation of broadband mobile.
UMTS Report 09 (2000a). The UMTS fourth-generation marketstructuring the service revenues opportunities, UMTS Forum.

UMTS Report 13 (2001b). Fourth generation market-phase II: Structuring the service revenue opportunities.

Velmurugan, M. S., \& Velmurugan, M. S. (2017). Information technology adoption on $3 \mathrm{G}$ mobile phone in India: the empirical analyses with SPSS 20, SmartPLS2.0M3 and LISREL8.80 - part 2. International Journal of Business Innovation and Research (IJBIR), 13 (2).

Venkatesh, V. \& Davis, F.D. (2000). A theoretical extension of the technology acceptance model: Four longitudinal field studies. Management Science, 46 (2).

Wikipedia. The history of mobile phone. (n.d.). Retrieved from https://en.wikipedia.org/wiki/history_of_mobile_phone

$\mathrm{Xu}$, Chao., Hu, Shaohan., Zheng, Wei., Abdelzaher, Tarek F., Hui, Pan., Xie, Zhiheng., ......Liu., \& Stankovi, John A. C. (2017, June 1). Efficient 3G/4G budget utilization in mobile sensing applications. IEEE Transactions on Mobile Computing, 16 (6).

$--0-$

Online Archive: https://abc.us.org/ojs/index.php/abr/issue/archive 